\title{
Influence of angiotensin converting enzyme inhibition on pump function and cardiac contractility in patients with chronic congestive heart failure
}

Leo H B Baur, Johan J Schipperheyn, Jan Baan, Arnoud van der Laarse, Beert Buis, Ernst E van der Wall, Volkert Manger Cats, Arjan D van Dijk, Jacobus A K Blokland, Marijke Frölich, Albert V G Bruschke

\begin{abstract}
Eleven patients with coronary artery disease and chronic heart failure were studied before and three months after the angiotensin converting enzyme inhibitor enalapril was added to their frusemide medication. The following were measured: left ventricular pressure and volume with transient occlusion of the inferior vena cava, radionuclide angiography, and hormone concentrations in plasma. As in other reported studies, the clinical condition of the patients improved and their exercise tolerance increased moderately. Addition of enalapril reduced end diastolic and systolic pressure, reduced ventricular volume, and concomitantly increased the ejection fraction. The end systolic pressure-volume relation shifted to the left as it did in a similar animal study. In the animal study unloading by a vasodilator did not induce a leftward shift, so it can be inferred that in the present study unloading combined with a decrease in the angiotensin concentration was instrumental in remodelling the heart. Though unloading was expected to have a beneficial effect on the oxygen supply/demand ratio of the heart, the patients still showed the same drop in the ejection fraction during exercise as they did before treatment with enalapril, and early diastolic filling did not improve. Normally, regression of cardiac dilatation is only found if pump function improves; the present study showed that unloading in combination with angiotensin converting enzyme inhibition reshapes the ventricle without improving intrinsic pump function.
\end{abstract}

The addition of an angiotensin converting enzyme inhibitor such as enalapril to the conventional treatment of rest, salt restriction, and a diuretic has become an established approach in the treatment of patients with severe congestive cardiac failure. Angiotensin converting enzyme inhibition produces arterial and venous vasodilatation and improves cardiac pump function by unloading the left ventricle. As a result the clinical condition improves and the exercise tolerance ${ }^{1-3}$ and life expectancy of the patients increases. ${ }^{4}$

After myocardial infarction the ventricle dilates mainly as a result of slippage of bundles of myocardial cells. ${ }^{5}$ Unloading of the heart by angiotensin converting enzyme inhibition reduces ventricular volume, ${ }^{167}$ mainly by lowering the filling pressure, but perhaps also by remodelling, because extensive postinfarct dilatation seems to be reversible. Moreover, it is clear that the observed improvement in exercise tolerance is due not only to better pump function but also to a more efficient distribution of the peripheral circulation. It is a matter of debate whether the pump function improves only because of the unloading and remodelling or because there is also some improvement in the intrinsic function of the cardiac muscle.

Intracoronary injection of angiotensin converting enzyme inhibitors blocked the direct inotropic action of angiotensin $\mathrm{II},{ }^{8-10}$ but the long term effect may be to enhance muscle function by improving metabolism and allowing hypoxic muscle cells to recover their contractility.

We studied 11 patients with chronic congestive heart failure with dyspnoea class IIIV (New York Heart Association) before and after three months of treatment with enalapril added to a regimen of diuretics, salt restriction and, in some, digitalis or antiarrhythmic agents. Haemodynamic function was extensively measured. We used on line pressurevolume studies with transient occlusion of the inferior vena cava and radionuclide angiography at rest and during exercise to identify the effects of unloading, of remodelling, and of a possible improvement of myocardial function.

\section{Patients and methods}

PATIENTS

Eleven men (aged 48-66 (mean 59)) with chronic congestive heart failure caused by coronary artery disease and myocardial infarction completed the study within a period of 18 months. The patients gave their informed consent and the protocol of the study was approved by the hospital ethics committee. Eighteen patients entered the study but seven did not complete it. Three died suddenly during follow up, one underwent a coronary bypass operation, and three stopped the treatment with enalapril because of side effects.

Inclusion criteria were cardiac failure class II-IV (New York Heart Association) and a left 
ventricular ejection fraction $<45 \%$ at rest, as measured by radionuclide angiography. Stable exercise dependent angina was not a reason for exclusion and patients with mild mitral regurgitation secondary to ventricular dilatation or papillary muscle dysfunction were also not excluded. Exclusion criteria were severe hypertension, myocardial infarction less than four months before, albuminuria, serum creatinine concentrations $>150 \mu \mathrm{mol} / 1$, and valvar or congenital heart disease.

\section{STUDY PROTOCOI}

Patients were admitted to the cardiology ward once before treatment and again after three months of treatment. During each admission an exercise test was performed with radionuclide imaging of the left ventricle, followed after one or two days by a right and left heart catheterisation with pressure-volume measurements and balloon occlusion of the inferior vena cava to determine the pressurevolume relations of the left ventricle. Blood samples were taken with appropriate precautions to measure plasma renin and angiotensin converting enzyme activity and concentrations of angiotensin II and atrial natriuretic peptide in the resting state. All prior medication was continued throughout the study and treatment with enalapril was started ( $\leqslant 20 \mathrm{mg} /$ day). The first dose was given after the haemodynamic tests were completed and the effects were carefully monitored. After three months all variables were measured again.

\section{BIOCHEMICAL MEASUREMENTS}

To exclude the effect of physical activity blood samples were taken at 6.00 am before the patients rose. Blood samples for the measurement of angiotensin II and angiotensin converting enzyme activity were collected separately and a combination of EDTA and phenanthroline or of heparin and aprotinin was added, respectively. The samples were kept on ice, centrifuged in a precooled centrifuge, and stored at $-70^{\circ} \mathrm{C}$. Angiotensin converting enzyme activity was measured spectrophotometrically with a test kit (Paesel, Frankfurt, Germany) that had $15 \mathrm{U} / 1$ as its lower limit of reference range. Plasma renin activity was measured by radioimmunoassay of the angiotensin I generated from the $\alpha_{2}$ precursor under standard conditions (Baxter, Cambridge, Massachusetts, USA). Enalapril was tested for possible interference in the assay and concentrations of the drug up to $50 \mu \mathrm{g} / \mathrm{ml} \mathrm{did}$ not show such effect. The reference range for angiotensin II in normotensive individuals is 0-25 pmol/1 plasma (median $18 \mathrm{pmol} / \mathrm{l}$ ). Normal values of plasma renin activity in ambulant individuals (with unrestricted salt intake) are $1.67(0.83) \mu \mathrm{g} / 1$ per hour. After extraction on Seppac C18 column (Waters, Bedford, Massachusetts, USA) angiotensin II was measured by a radioimmunoassay with antibodies generated in rabbits. Atrial natriuretic peptide was measured by a radioimmunoassay (Immuno Nuclear, Amsterdam, The Netherlands). The upper limit of the reference range was $68 \mathrm{pg} / \mathrm{ml}$ in plasma.

\section{EXERCISE TESTS}

The exercise test was performed in combination with radionuclide imaging on a normal upright bicycle ergometer. The workload was increased stepwise from $10 \mathrm{~W}$ by $10 \mathrm{~W}$ every minute until exhaustion. A Toshiba 40A gamma camera was used to make two radionuclide scintigrams, the former in the 10 minutes immediately before exercise and the latter during the last three minutes of exercise. Red blood cells were labelled in vivo by injecting $750 \mathrm{MBq}(20 \mathrm{mCi})$ technetium-99m. Gated radionuclide angiograms were made in the $40^{\circ}$ left anterior oblique position with a $30^{\circ}$ caudocranial tilt to obtain optimal separation of the right and left ventricles. The volume of the left ventricle was calculated from the number of ventricular counts and the activity of a blood sample measured simultaneously. Data were collected in a matrix of $64 \times 64$ pixels.

\section{HAEMODYNAMIC MEASUREMENTS}

A $7 \mathrm{~F}$ thermodilution Swan-Ganz flow directed catheter was introduced into a femoral vein and its tip was floated into a branch of a pulmonary artery. It was used to measure pressures and cardiac output (by thermodilution and the Fick method). An $8 \mathrm{~F}$ Cordis pigtail catheter with a tip manometer was introduced percutaneously into the femoral artery and advanced into the left ventricle. It was used for left ventricular angiography and simultaneous pressure measurements. Left ventricular angiograms were filmed in two directions-the $30^{\circ}$ right anterior oblique and the $60^{\circ}$ left anterior oblique positions. Later the angiograms were digitised and left ventricular end diastolic and end systolic volumes were estimated by a Philips Analytical Processing Unit system.

The time constant for the exponential decay of pressure $(\tau)$ was calculated according to the method described by Weiss et al. ${ }^{11}$ Subsequently a second $8 \mathrm{~F}$ custom made pigtail catheter, with ten electrodes (Webster Labs, Baldwin Park, California, USA), ${ }^{1213}$ was introduced into the left ventricle to measure volume. Its tip was carefully positioned in the apex and a $0.03 \mathrm{~mA}$ root mean square $20 \mathrm{kHz}$ alternating current was passed between the most apical electrode and the one close to the aortic valve. Left ventricular volume was calculated on line from the voltages between adjacent pairs of electrodes between the current electrodes ${ }^{1314}$ by an analogue signal conditioner processor (Sigma-5, Leycom, Oestgeest, The Netherlands). Combined with the pressure signal from the tip manometer pressure-volume loops were displayed continuously on an X-Y oscilloscope.

To obtain pressure-volume loops under changing loading conditions a balloon catheter (Meditech, Watertown, Massachusetts, USA) was introduced percutaneously into the femoral vein and the balloon was positioned in the inferior vena cava. When the balloon was inflated with carbon dioxide the venous return to the heart was reduced sufficiently to allow the end systolic pressure-volume relation ${ }^{15-17}$ and the relation between $\mathrm{dP} / \mathrm{dt}_{\max }$ and end diastolic volume $^{18}$ to be determined. 
Absolute values of end diastolic and end systolic volumes measured by conductance catheter were calibrated afterwards against the radionuclide data in eight patients, or, if these data were not available, the volumes were estimated from the ventriculograms.

We used Student's paired $t$ test to compare data obtained before and after treatment.

\section{Results}

CLINICAL RESPONSE TO TREATMENT

Before treatment two patients were in heart failure class II, eight in class III, and one in class IV. On average they had been in heart failure for 20 months (range 1-96 months). Two patients had moderate angina and two had severe angina. Five patients were treated with digoxin, 10 with frusemide, and three with long acting nitrates. In addition, one patient took flecainide and another amiodarone. All patients were given anticoagulant treatment with coumadin. The cardiac medication was continued without change throughout the study.

Seven patients tolerated a dosage of $20 \mathrm{mg}$ enalapril a day and four were given a daily dose of $10 \mathrm{mg}$. Eight patients improved clinically but in three the clinical condition remained unchanged. Two of the four patients with angina reported a reduction in episodes of pain.

\section{BIOCHEMICAL RESPONSES}

Treatment reduced converting enzyme activity in the plasma from an average of $14.06 \mathrm{U} / 1$ to $2.45 \mathrm{U} / 1(\mathrm{p}<0.0001)$. Plasma renin activity before treatment was high (mean $6.33 \mu \mathrm{g} / 1$ per hour) and it increased to $24.8 \mu \mathrm{g} / 1$ per hour after treatment ( $p<0.005)$. Plasma concentrations of angiotensin II were raised before treatment $(30.0 \mathrm{pmol} / \mathrm{l})$ and dropped to 10.1 pmol $/ 1$ after treatment $(\mathrm{p}<0.05)$. Initially the plasma concentration of atrial natriuretic factor was considerably raised $(189 \mathrm{pg} / \mathrm{ml})$. After three months of treatment it had dropped to $103 \mathrm{pg} / \mathrm{ml}$ ( $\mathrm{p}<0.05$ ). Baseline aldosterone concentration was also raised $(0.8 \mu \mathrm{mol} / \mathrm{l})$ before treatment and it fell (but not significantly) to $0.4 \mu \mathrm{mol} / 1$ during treatment.

HAEMODYNAMIC RESPONSES TO ENALAPRIL

Table 1 shows the haemodynamic data. Right atrial pressure, mean pulmonary artery pressure, pulmonary capillary pressure, and left ventricular end diastolic pressure all declined after treatment. Mean aortic pressure also fell. Cardiac index remained practically unchanged. Systemic vascular resistance fell significantly, while the pulmonary vascular resistance also declined but not significantly.

Table 2 shows the volume data obtained by radionuclide angiography. The end diastolic and end systolic volume indices of the left ventricle fell significantly. In nine patients in whom pressure-volume loops could be recorded both before and after treatment, the diastolic pressure-volume relation shifted to the left (fig 1). The ejection fraction at rest increased slightly from $0.24(0.09)$ to 0.30 $(0.11)(\mathrm{p}<0.05)$.

\section{REMODELLING OF THE VENTRICLE}

Pressure-volume loops could be recorded in nine patients. In two (patients 2 and 5 ) it was not possible to position the conductance catheter in the correct position. Figure 1 shows the shift of the two families of pressure-volume loops, obtained by obstructing the inferior vena cava before and after treatment in patient 4. The diastolic pressure-volume relation was shifted towards the left, which indicates that

Table 1 Haemodynamic function before treatment and three months after treatment with enalapril

\begin{tabular}{|c|c|c|c|c|c|c|c|c|c|c|c|c|}
\hline $\begin{array}{l}\text { Case } \\
\text { no }\end{array}$ & $\begin{array}{l}H R \\
\text { (beats/min) }\end{array}$ & $\begin{array}{l}M P R A \\
(m m H g)\end{array}$ & $\begin{array}{l}M P A P \\
(m m H g)\end{array}$ & $\begin{array}{l}M P C P \\
(m m \mathrm{Hg})\end{array}$ & $\begin{array}{l}L V E D P \\
(m m \mathrm{Hg})\end{array}$ & $\begin{array}{l}M A O P \\
(m m \mathrm{Hg})\end{array}$ & $\begin{array}{l}C I \\
(l / \min )\end{array}$ & $\begin{array}{l}\text { PVR } \\
\left(\text { N.s. m } m^{-5}\right) \\
\left(\times 10^{5}\right)\end{array}$ & $\begin{array}{l}\text { SVR } \\
\left(N . s . m^{-5}\right) \\
\left(\times 10^{5}\right)\end{array}$ & $\begin{array}{l}L V E F \\
(\%)\end{array}$ & $\begin{array}{l}d P / d t_{\max } \\
(m m \mathrm{Hg} / \mathrm{s})\end{array}$ & $\begin{array}{l}\tau \\
(m s)\end{array}$ \\
\hline \multicolumn{13}{|c|}{ Before treatment } \\
\hline $\begin{array}{r}1 \\
2 \\
3 \\
4 \\
5 \\
6 \\
7 \\
8 \\
9 \\
10 \\
11\end{array}$ & $\begin{array}{r}59 \\
111 \\
70 \\
61 \\
90 \\
48 \\
10 \\
105 \\
83 \\
100 \\
85\end{array}$ & $\begin{array}{r}15 \\
9 \\
5 \\
4 \\
7 \\
4 \\
36 \\
8 \\
14 \\
5 \\
5\end{array}$ & $\begin{array}{l}35 \\
43 \\
21 \\
16 \\
22 \\
13 \\
35 \\
20 \\
33 \\
43 \\
31\end{array}$ & $\begin{array}{l}25 \\
30 \\
12 \\
10 \\
16 \\
11 \\
26 \\
18 \\
\frac{28}{-}\end{array}$ & $\begin{array}{l}20 \\
26 \\
10 \\
12 \\
15 \\
12 \\
22 \\
25 \\
20 \\
25 \\
25\end{array}$ & $\begin{array}{r}72 \\
71 \\
101 \\
84 \\
84 \\
94 \\
81 \\
70 \\
95 \\
87 \\
86\end{array}$ & $\begin{array}{l}1.5 \\
2 \cdot 4 \\
3.6 \\
2 \cdot 2 \\
2 \cdot 8 \\
2 \cdot 7 \\
1.8 \\
1.1 \\
2 \cdot 3 \\
2 \cdot 3 \\
2.8\end{array}$ & $\begin{array}{r}287 \\
246 \\
92 \\
130 \\
79 \\
72 \\
205 \\
77 \\
260 \\
320 \\
87\end{array}$ & $\begin{array}{l}1630 \\
1139 \\
1152 \\
1752 \\
1059 \\
1352 \\
1648 \\
2384 \\
1268 \\
1680 \\
1212\end{array}$ & $\begin{array}{l}38 \\
30 \\
34 \\
42 \\
21 \\
38 \\
23 \\
12 \\
28 \\
28 \\
15\end{array}$ & $\begin{array}{r}659 \\
970 \\
1553 \\
897 \\
-541 \\
541 \\
1316 \\
665 \\
1200 \\
1047 \\
1018\end{array}$ & $\begin{array}{l}63 \\
75 \\
31 \\
66 \\
61 \\
58 \\
71 \\
60 \\
62 \\
40\end{array}$ \\
\hline $\begin{array}{l}\text { Mean } \\
\text { (SD) }\end{array}$ & $\begin{array}{l}83 \\
21\end{array}$ & $\begin{array}{l}7 \cdot 5 \\
3 \cdot 7\end{array}$ & $\begin{array}{l}28 \cdot 5 \\
10 \cdot 1\end{array}$ & $\begin{array}{r}19 \cdot 6 \\
7 \cdot 4\end{array}$ & $\begin{array}{r}19 \cdot 3 \\
5 \cdot 7\end{array}$ & $\begin{array}{r}84.0 \\
9.8\end{array}$ & $\begin{array}{l}2.3 \\
0.6\end{array}$ & $\begin{array}{r}169 \\
92\end{array}$ & $\begin{array}{r}1480 \\
371\end{array}$ & $\begin{array}{l}28 \\
15\end{array}$ & $\begin{array}{l}987 \\
300\end{array}$ & $\begin{array}{l}59 \\
13\end{array}$ \\
\hline \multicolumn{13}{|c|}{ After three months' treatment with enalapril } \\
\hline $\begin{array}{r}1 \\
2 \\
3 \\
4 \\
5 \\
6 \\
7 \\
8 \\
9 \\
10 \\
11\end{array}$ & $\begin{array}{r}65 \\
100 \\
77 \\
69 \\
88 \\
61 \\
72 \\
92 \\
65 \\
107 \\
79\end{array}$ & $\begin{array}{r}13 \\
5 \\
6 \\
3 \\
7 \\
3 \\
5 \\
3 \\
11 \\
3 \\
2\end{array}$ & $\begin{array}{l}29 \\
36 \\
17 \\
17 \\
15 \\
14 \\
25 \\
25 \\
28 \\
16 \\
27\end{array}$ & $\begin{array}{r}25 \\
25 \\
9 \\
9 \\
13 \\
7 \\
13 \\
18 \\
14 \\
11 \\
11\end{array}$ & $\begin{array}{r}25 \\
25 \\
10 \\
12 \\
13 \\
8 \\
14 \\
18 \\
11 \\
14 \\
25\end{array}$ & $\begin{array}{r}72 \\
60 \\
105 \\
92 \\
74 \\
82 \\
67 \\
68 \\
58 \\
70 \\
73\end{array}$ & $\begin{array}{l}1.7 \\
2.9 \\
3.4 \\
2.5 \\
2.1 \\
3.8 \\
1.6 \\
2.0 \\
2.6 \\
3.0 \\
2.3\end{array}$ & $\begin{array}{r}112 \\
164 \\
88 \\
153 \\
35 \\
70 \\
300 \\
139 \\
282 \\
75 \\
81\end{array}$ & $\begin{array}{r}1532 \\
846 \\
1100 \\
1575 \\
1155 \\
803 \\
1569 \\
1372 \\
852 \\
1011 \\
1187\end{array}$ & $\begin{array}{l}33 \\
35 \\
31 \\
42 \\
29 \\
41 \\
35 \\
19 \\
23 \\
29 \\
23\end{array}$ & $\begin{array}{r}697 \\
668 \\
1716 \\
844 \\
674 \\
638 \\
711 \\
1218 \\
1370 \\
1141\end{array}$ & $\begin{array}{l}78 \\
35 \\
38 \\
59 \\
35 \\
57 \\
45 \\
55 \\
27 \\
55\end{array}$ \\
\hline $\begin{array}{l}\text { Mean } \\
\text { (SD) }\end{array}$ & $\begin{array}{l}80 \\
15\end{array}$ & $\begin{array}{l}5 \cdot 5 \\
3 \cdot 4\end{array}$ & $\begin{array}{r}22.5 \\
6.8\end{array}$ & $\begin{array}{r}14 \cdot 1 \\
5 \cdot 9\end{array}$ & $\begin{array}{r}15.9 \\
6 \cdot 1\end{array}$ & $\begin{array}{l}74.5 \\
13 \cdot 2\end{array}$ & $\begin{array}{l}2.5 \\
0.7\end{array}$ & $\begin{array}{r}136 \\
82\end{array}$ & $\begin{array}{r}1182 \\
280\end{array}$ & $\begin{array}{r}30 \cdot 9 \\
7 \cdot 0\end{array}$ & $\begin{array}{l}998 \\
337\end{array}$ & $\begin{array}{l}48 \\
15\end{array}$ \\
\hline p & & 0.001 & 0.05 & 0.05 & 0.05 & 0.05 & & & 0.05 & 0.05 & & \\
\hline
\end{tabular}

p CI, cardiac index per $\mathrm{m}^{2}$ body surface area; HR, heart ra, vascular resistance; SVR, systemic vascular resistance. 
Table 2 Responses measured during technetium-99m exercise testing

\begin{tabular}{|c|c|c|c|c|c|c|c|c|c|c|}
\hline $\begin{array}{l}\text { Case } \\
\text { no }\end{array}$ & $\underset{(W)}{M W L}$ & $\begin{array}{l}\text { HR rest } \\
\text { (beats } / \text { min) }\end{array}$ & $\begin{array}{l}\text { HR load } \\
\text { (beats } / \text { min) }\end{array}$ & $\begin{array}{l}\text { LVEF rest } \\
(\%)\end{array}$ & $\begin{array}{l}\text { LVEF load } \\
(\%)\end{array}$ & $\begin{array}{l}D E F \\
(\%)\end{array}$ & $\begin{array}{l}\text { EDVI rest } \\
(\mathrm{ml})\end{array}$ & $\begin{array}{l}\text { ESVI rest } \\
(\mathrm{ml})\end{array}$ & $\begin{array}{l}\text { SVI rest } \\
(\mathrm{ml})\end{array}$ & $\begin{array}{l}\text { HRPP } \\
\left(\begin{array}{l}\mathrm{mm} \mathrm{Hg} / \mathrm{min}) \\
\left(\times 10^{3}\right)\end{array}\right.\end{array}$ \\
\hline \multicolumn{11}{|c|}{ Before treatment } \\
\hline $\begin{array}{r}1 \\
2 \\
3 \\
4 \\
5 \\
6 \\
7 \\
8 \\
9 \\
10 \\
11\end{array}$ & $\begin{array}{r}40 \\
50 \\
110 \\
70 \\
100 \\
110 \\
90 \\
80 \\
80 \\
60 \\
120\end{array}$ & $\begin{array}{r}50 \\
100 \\
65 \\
60 \\
88 \\
66 \\
100 \\
112 \\
82 \\
90 \\
95\end{array}$ & $\begin{array}{r}90 \\
145 \\
105 \\
100 \\
135 \\
100 \\
150 \\
142 \\
120 \\
108 \\
120\end{array}$ & $\begin{array}{l}18 \\
20 \\
32 \\
19 \\
21 \\
38 \\
24 \\
12 \\
42 \\
19 \\
21\end{array}$ & $\begin{array}{l}14 \\
19 \\
32 \\
24 \\
13 \\
31 \\
15 \\
12 \\
37 \\
19 \\
18\end{array}$ & $\begin{array}{r}-4 \\
-1 \\
0 \\
5 \\
-8 \\
-7 \\
-9 \\
0 \\
-5 \\
0 \\
-3\end{array}$ & $\begin{array}{l}104 \\
123 \\
142 \\
125 \\
189 \\
116 \\
103 \\
121 \\
121 \\
153 \\
135\end{array}$ & $\begin{array}{r}85 \\
98 \\
109 \\
101 \\
149 \\
72 \\
78 \\
107 \\
87 \\
124 \\
107\end{array}$ & $\begin{array}{l}19 \\
25 \\
33 \\
24 \\
40 \\
44 \\
25 \\
14 \\
34 \\
29 \\
28\end{array}$ & $\begin{array}{r}9.90 \\
18.85 \\
9.95 \\
15.55 \\
24.30 \\
15.55 \\
24.00 \\
18.46 \\
22.80 \\
14.58 \\
20.40\end{array}$ \\
\hline $\begin{array}{l}\text { Mean } \\
\text { (SD) }\end{array}$ & $\begin{array}{l}83 \\
25\end{array}$ & $\begin{array}{l}83 \\
19\end{array}$ & $\begin{array}{r}120 \\
20\end{array}$ & $\begin{array}{r}24 \\
9\end{array}$ & $\begin{array}{r}21 \\
8\end{array}$ & $\begin{array}{r}-3 \\
4\end{array}$ & $\begin{array}{r}130 \\
25\end{array}$ & $\begin{array}{r}102 \\
22\end{array}$ & $\begin{array}{r}29 \\
9\end{array}$ & $\begin{array}{r}18 \cdot 58 \\
4 \cdot 41\end{array}$ \\
\hline \multicolumn{11}{|c|}{ After three months' treatment with enalapril } \\
\hline $\begin{array}{r}1 \\
2 \\
3 \\
4 \\
5 \\
6 \\
7 \\
8 \\
9 \\
10 \\
11\end{array}$ & $\begin{array}{r}60 \\
100 \\
130 \\
75 \\
110 \\
90 \\
90 \\
125 \\
70 \\
60 \\
130\end{array}$ & $\begin{array}{l}70 \\
90 \\
63 \\
68 \\
90 \\
64 \\
80 \\
90 \\
75 \\
77 \\
74\end{array}$ & $\begin{array}{r}100 \\
125 \\
100 \\
110 \\
125 \\
90 \\
135 \\
160 \\
120 \\
130 \\
150\end{array}$ & $\begin{array}{l}18 \\
27 \\
30 \\
20 \\
23 \\
49 \\
30 \\
22 \\
53 \\
27 \\
27\end{array}$ & $\begin{array}{l}-\overline{23} \\
30 \\
16 \\
19 \\
36 \\
18 \\
16 \\
47 \\
19 \\
21\end{array}$ & $\begin{array}{r}- \\
-4 \\
0 \\
-4 \\
-4 \\
-13 \\
-12 \\
-6 \\
-6 \\
-8 \\
-6\end{array}$ & $\begin{array}{r}94 \\
145 \\
101 \\
64 \\
197 \\
73 \\
92 \\
101 \\
96 \\
101 \\
126\end{array}$ & $\begin{array}{r}77 \\
106 \\
71 \\
51 \\
152 \\
37 \\
74 \\
79 \\
74 \\
74 \\
92\end{array}$ & $\begin{array}{l}17 \\
39 \\
30 \\
13 \\
45 \\
36 \\
18 \\
22 \\
22 \\
27 \\
34\end{array}$ & $\begin{array}{l}13 \cdot 50 \\
15 \cdot 00 \\
19 \cdot 50 \\
21 \cdot 45 \\
20 \cdot 00 \\
15 \cdot 75 \\
21 \cdot 60 \\
18 \cdot 40 \\
19 \cdot 20 \\
19 \cdot 50 \\
26 \cdot 25\end{array}$ \\
\hline $\begin{array}{l}\text { Mean } \\
\text { (SD) }\end{array}$ & $\begin{array}{l}90 \\
28\end{array}$ & $\begin{array}{l}77 \\
10\end{array}$ & $\begin{array}{r}122 \\
21\end{array}$ & $\begin{array}{l}30 \\
11\end{array}$ & $\begin{array}{l}22 \\
12\end{array}$ & $\begin{array}{r}-6 \\
4\end{array}$ & $\begin{array}{r}108 \\
37\end{array}$ & $\begin{array}{l}81 \\
22\end{array}$ & $\begin{array}{l}28 \\
10\end{array}$ & $\begin{array}{r}19 \cdot 10 \\
3.52\end{array}$ \\
\hline $\mathrm{p}$ & & & & 0.05 & & 0.05 & 0.05 & $0 \cdot 01$ & & \\
\hline
\end{tabular}

DEF, reduction of ejection fraction at rest; EDVI, end diastolic volume per $\mathrm{m}^{2}$ body surface area; ESVI, end systolic volume per $\mathrm{m}^{2}$ body surface area; $\mathrm{HR}$ res heart rate at rest; HR load, heart rate during maximal exercise; HRPP, heart rate $\times$ pressure product; LVEF rest, left ventricular ejection fraction at rest; LVEF load, left ventricular ejection fraction during maximal exercise; MWL, maximal workload; SVI, stroke volume per $\mathrm{m}^{2}$ body surface area.

Figure 1 Plots of representative pressurevolume loops during preload reduction by occlusion of the inferior vena cava before $(A)$, and after three months' treatment with enalapril (B). The pressure-volume loops shifted to the left without a change in the slope of the end systolic pressure-volume reaction.
Figure 2 Shift in the end diastolic pressure-volume relation before occlusion of the inferior vena cava in nine patients before $(A)$ and after $(B)$ three months of treatment with enalapril. the passive diastolic properties of the ventricle had changed. This was consistently seen in all patients in whom a pressure-volume loop could be recorded. Figure 2 shows the shifts of the end diastolic volumes of the whole group.
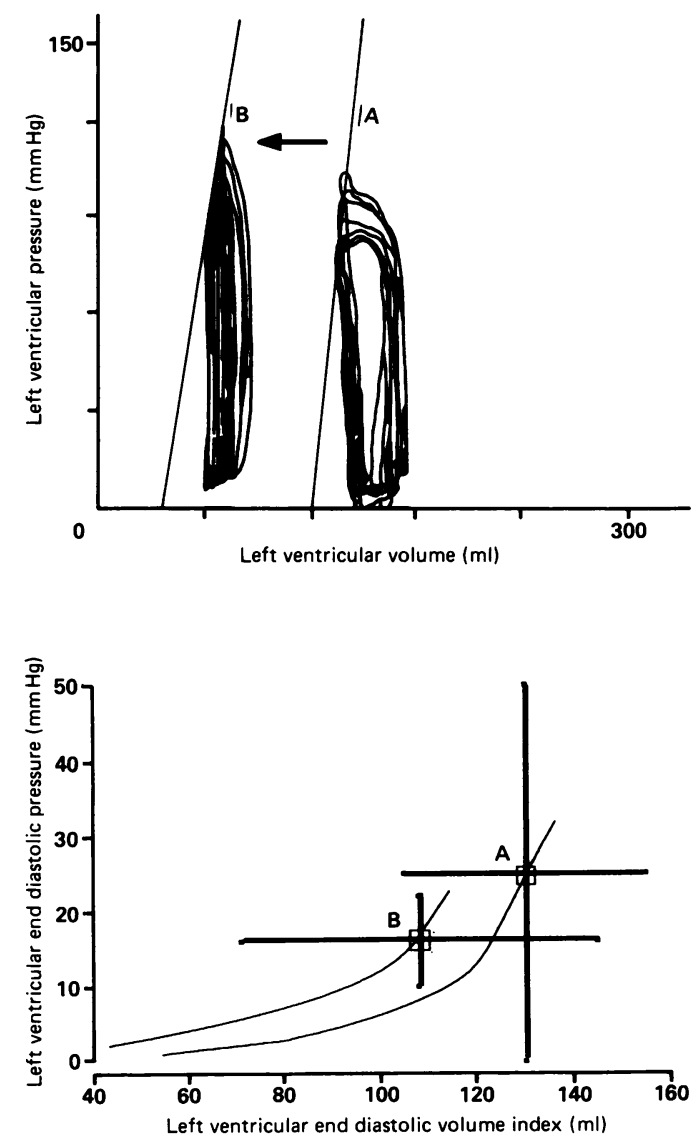

EXERCISE TOLERANCE

In seven patients the maximum workload increased, in two it remained unchanged, and in two it decreased after treatment (table 2). On average the maximum exercise capacity increased slightly but not significantly. Heart rate at maximal workload remained practically the same, as did the rate-pressure product. Though eight patients felt that their exercise tolerance had improved, only four increased their maximum rate-pressure product. Three of them did so at the expense of a considerable drop of the ejection fraction during exercise, more than observed before treatment; in the fourth patient the ejection fraction was not measured after treatment.

\section{INDICES OF CONTRACTILITY}

On average the values of $\mathrm{dP} / \mathrm{dt}_{\max }$ were below normal before (987 (300) $\mathrm{mm} \mathrm{Hg} / \mathrm{s}$ ) and remained unchanged after treatment $(988$ (337) $\mathrm{mm} \mathrm{Hg} / \mathrm{s}$ ). The inferior vena cava could be obstructed effectively in only four patients; in the other five patients in whom pressurevolume loops were recorded the inflation of the balloon did not reduce diastolic pressure and volume either before or after treatment. Figure 3 shows the typical almost parallel shift to the left of the end systolic pressure-volume relation, which indicated almost unchanged end systolic pressure-volume relation. The mean volume intercept shifted from 128 (65) to 55 (24) $\mathrm{ml}$ and the slope remained practically the same $(0.34(0.22) \mathrm{mm} \mathrm{Hg} / \mathrm{ml}$ before and 0.28 $(0.10) \mathrm{mm} \mathrm{Hg} / \mathrm{ml}$ after treatment). The slope of the relation between $\mathrm{dP} / \mathrm{dt}_{\max }$ and end diastolic volume also remained practically unchangedmean $1.64(2.31) \mathrm{mm} \mathrm{Hg} \cdot \mathrm{s}^{-1} \cdot \mathrm{ml}^{-1}$ before and $1.23(0.48) \mathrm{mm} \mathrm{Hg}^{-1} \cdot \mathrm{ml}^{-1}$ after treatment. 

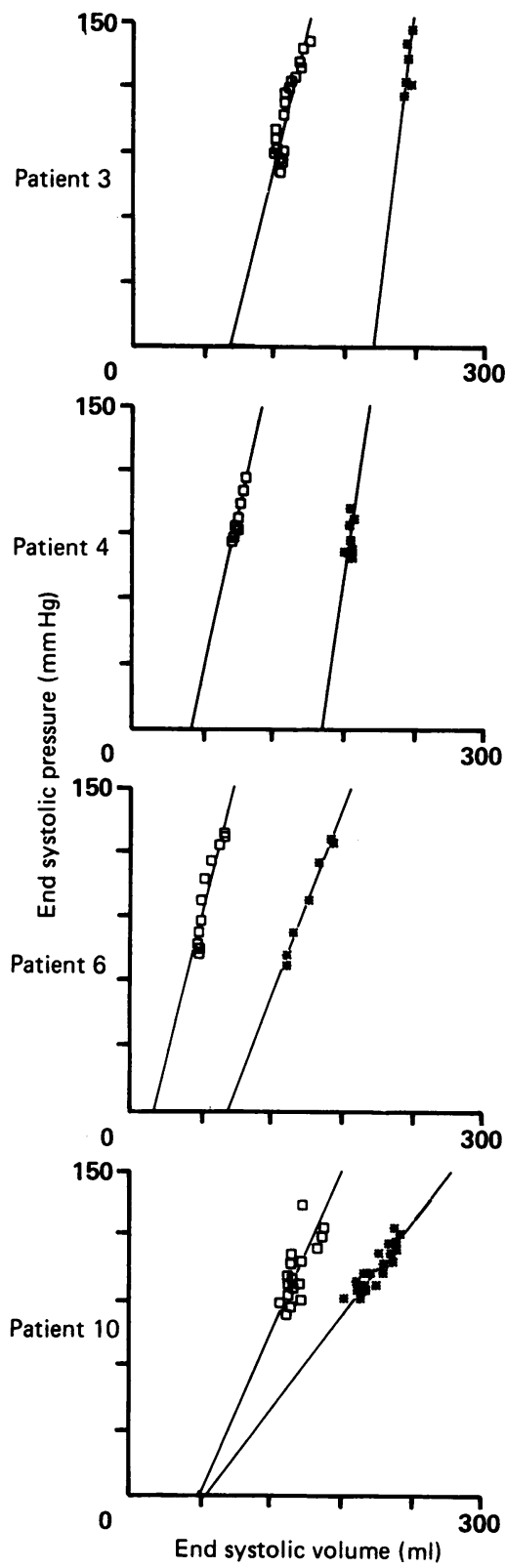

Figure 3 (Left) End systolic pressure-volume relation before and after three months treatment with enalapril in four patients with successful preload reduction by occlusion of the inferior vena cava. (Right) Relation between $d P / d t_{\text {max }}$ and end diastolic volume before and after three months of treatment with enalapril in the same four patients with successful preload reduction by occlusion of the inferior vena cava.

\section{METABOLIC CONDITION OF THE HEART}

Normally the left ventricular ejection fraction increases during exercise and a drop or even the absence of a rise at maximum workload is taken as a sign of higher overt myocardial ischaemia or hypoxic suppression of contractility caused by a limited coronary reserve. Before treatment the mean ejection fraction for the group decreased from $0.24(0.09)$ at rest to $0.21(0.08)$ at maximum workload; it fell in seven patients, remained unchanged in three, and increased from 0.19 to 0.24 in one. After treatment the ejection fraction decreased during exercise in nine patients, remained constant in one, and was measured only at rest in one patient. On average, the ejection fraction after treatment dropped from $0.30(0.11)$ at rest to $0.22(0.12)$ at maximum workload. In seven patients the fall in the ejection fraction during exercise became more pronounced, and in three of these patients the maximal rate-pressure product increased. The only patient whose ejection fraction increased during exercise and who attained a rate-pressure product of $15.5\left(\times 10^{3}\right) \mathrm{mm} \mathrm{Hg}$ / min, exercised to a rate-pressure product of $21.4\left(\times 10^{3}\right) \mathrm{mm} \mathrm{Hg} / \mathrm{min}$ after treatment but his ejection fraction fell.

Because relaxation in early diastole is an active, energy dependent process, the negative peak $\mathrm{dP} / \mathrm{dt}$ and the time constant $\tau$ of the exponential decay of pressure immediately after a negative peak $\mathrm{dP} / \mathrm{dt}$ are both regarded as indices of the metabolic condition of the heart muscle. There was little change in the peak negative $\mathrm{dP} / \mathrm{dt}(903$ (190) $\mathrm{mm} \mathrm{Hg} / \mathrm{s}$, and 891 (229) $\mathrm{mm} \mathrm{Hg} / \mathrm{s}$ ) (NS). The value of $\tau$ also did not change significantly after treatment (table 1).

\section{Discussion}

Earlier studies showed that addition of an angiotensin converting enzyme inhibitor to the frusemide treatment of patients with severe cardiac failure improved their clinical condition, exercise tolerance, and prognosis. ${ }^{41920}$ After three months of treatment the left ventricle was smaller and the heart produced the same cardiac output at a lower filling pressure against a lower aortic pressure. ${ }^{15}$ The present study confirms these results. Biochemical data show that the inhibition of the angiotensin converting enzyme was effective in all patients and that the angiotensin II and atrial natriuretic concentrations were reduced. Most patients felt better and their maximum workload increased. As a result of the treatment the pressure-volume loops shifted to the left and the recordings showed that the support structure of the ventricle had changed. Figure 1 shows that the reduction of diastolic ventricular volume achieved by lowering end diastolic pressure was much more important than the slight changes induced by an acute reduction of pressure of the same magnitude. This shows that the collagen support structure of the heart has indeed been reshaped.

A shift of the diastolic pressure-volume relation of the human left ventricle under the influence of enalapril has not been reported before, but similar results have been obtained experimentally by treating rats with chronic large myocardial infarctions with captopril. ${ }^{21}$ Unloading the heart with a predominantly arterial vasodilator, hydralazine, did not produce such an effect. ${ }^{22}$ From this it can be inferred that the ventricle is reshaped only because unloading is combined with a reduction of the angiotensin concentration. This conditional role of a reduction of angiotensin is supported by the results of experimental studies that point to a crucial role of such reduction in changing the collagen structure of the heart. A comparison of the effects of different types of hypertension and of angiotensin converting enzyme inhibition on rat hearts showed that renovascular hypertension induced cardiac hypertrophy with a higher collagen content than low renin hypertension caused by 
infrarenal banding. ${ }^{23}$ Regression of hypertrophy with angiotensin converting enzyme inhibition is accompanied not only by a reduction of collagen content but also by a considerable change in the ratio of type I and type III collagen..$^{25}$

Because the support structures in the heart were reshaped, the collagen tethers between bundles of cardiac fibres must first have been dissolved and later reformed. ${ }^{26}$ Acute unloading shifts the diastolic pressure-volume relation only slightly to the left, ${ }^{15}$ but in combination with the reconstruction of collagen tethers such a shift to a lower volume can be repeated until an appreciably lower volume is reached. This implies that remodelling of the heart will occur only if the heart is unloaded while the plasma concentrations of angiotensin II are simultaneously reduced. In an experimental study, treatment with a vasodilator that unloads the heart but activates the reninangiotensin-aldosterone system did not reduce heart size. ${ }^{22}$

In the acute experiment a leftward shift of the end systolic pressure-volume relation is usually interpreted as a sign of improved contractility. ${ }^{152728}$ The same is true for the relation between $\mathrm{dP} / \mathrm{dt}_{\max }$ and end diastolic volume, ${ }^{1827}$ but is such interpretation still correct in a long term study in which the ventricle is considerably remodelled and reduced in size? We found no additional evidence of an improvement of intrinsic contractile function in this study. A direct positive effect of enalapril would have been unlikely, because angiotensin II was weakly inotropic in isolated cardiac muscle ${ }^{8-10}$ and angiotensin converting enzyme inhibitors had a weakly negative inotropic action. ${ }^{29} \mathrm{Con}$ tractile function might have improved, however, by improvement in the heart's metabolism. Coronary reserve is usually reduced in cardiac failure and regional hypoxia of the muscle may add to the problem of cardiac failure caused by previous infarctions. The unloading of the heart may have a beneficial effect on its metabolism by reducing oxygen consumption, but lowering coronary perfusion pressure may have an opposite effect. The present data on reduction of ejection fraction during exercise suggest that the net effect of the unloading treatment on the oxygen balance was negligible or in some patients even slightly negative. Nor did the data on ventricular relaxation indicate an improvement in cardiac metabolism. So there seems little reason to suppose that treatment with an angiotensin converting enzyme inhibitor in this group of patients improved intrinsic muscle function, despite the leftward shift of end systolic pressure-volume relation and the relation between $\mathrm{dP} / \mathrm{dt}_{\max }$ and end diastolic volume. The improvement of pump function seems to be solely the result of the remodelling of the heart, without recruitment of hitherto hypoxic fibres.

We thank Dr B van Meurs and Mr A van Benthum of Philips Medical Systems for their help with the calculations of ventricular volumes on the Philips APU-system.

This study was supported by a grant from Merck, Sharp and Dohme.
1 Sharpe DN. Enalapril in patients with chronic congestive heart failure: a placebo controlled randomized double blind study. Circulation 1984;70:271-8.

2 Franciosa JA. Effects of enalapril a new angiotensin converting enzyme inhibitor in a controllec

Coll Cardiol 1985;5:101-7.

Fitzpatrick D, Nicholls MG, Ikram H, Espiner EA Haemodynamic, hormonal, and electrolyte effects of enalapril in heart failure. Br Heart J 1983;50:163-9.

4 Consensus Trial Study Group. Effects of mortality in severe congestive heart failure. N Engl J Med 1987;316:1429-35.

5 Weisman HF, Bush DE, Mannis JA, Weisfeldt ML, Healy B. Cellular mechanisms of myocardial infarct expansion. Circulation 1988;78:186-201

6 Sharpe N, Smith H, Murphy J, Hannan S. Treatment of patients with symptomless left ventricular dysfunction after myocardial induction. Lancet 1988;i:255-9.

7 Kromer EP. Effectiveness of converting enzyme inhibition (enalapril) for mild congestive heart failure. Am J Cardio 1986;57:459-62.

8 Freer RJ, Pappano AJ, Peach MJ, et al. Mechanisms for the positive inotropic effect of angiotensin II on isolated cardiac muscle. Circ Res 1976;39:178-83.

9 Kobayashi M, Furukawa Y, Chiba S. Positive chronotropic and inotropic effects of angiotensin II in the dog heart. Eur and inotropic effects of angio

10 Koch Weser J. Myocardial actions of angiotensin. Circ Res 1964;14:337-44.

11 Weiss JL, Frederiksen JW, Weisfeldt ML. Hemodynamic determinants of the time-course of fall in canine left ventricular pressure. J Clin Invest 1976;58:751-60.

12 Baan J, Aouw Jong TT, Kerkhoff PLM, et al. Continuous stroke volume and cardiac output from intraventricular dimensions obtained with impedance catheter. Cardiovas Res 1981;15:328-34.

13 Baan J, Van der Velde ET, de Bruin HG, et al. Continuous measurement of left ventricular volume in animals and humans by conductance catheter. Circulation 1984, 70:812-23.

14 Mur G, Baan J. Computation of the input impedances of a catheter for cardiac volumetry. IEEE Trans Biomed Eng 1984;BME 31:448-53.

15 Thormann J, Kramer W, Kundler M, Kremer P, Schleppe $M$. Bestimmung der Wirkcomponenten von Amrinon durch kontinuierliche Analyse der Druck-Volumendurch kontinuierliche Analyse der Druck-VolumenBeziehungen: Anwendung der Conductance (Volumen) Katheter-technik und der Schnellen Lastveränderung
durch Ballonokklusion der vena cava inferior. $Z$ Kardiol durch Ballonokk

16 Kass DA, Mide M, Grave W, Drinker JA, Maughan WL Use of conductance (volume) catheter and transien inferior vena caval occlusion for rapid determination of pressure-volume relationship in man. Cathet Cardiovas Diagn 1988;15:192-202.

17 Kass DA, Yamazaki T, Burkhoff D, Maughan WL, Sagawa $K$. Determination of left ventricular endsystolic pressurevolume relationships by the conductance (volume) cath eter technique. Circulation 1986;73:586-95.

$18 \mathrm{Little}$ WC. The left ventricular $\mathrm{dP} / \mathrm{dt}_{\text {max }}$ enddiastolic volume relation in closed-chest dogs. Circ Res 1986;56:808-15.

19 Levine BT, Olivari MT, Garberg VRN, Sharkey SW, Cohn JN. Haemodynamic and clinical response to enalapril, a long acting converting enzyme inhibitor, in patients with cong acting converting enzyme inhibitor, in patients

20 Dunkman VB, Wilen M, Franciosa JA. Enalapril, a new angiotensin converting enzyme inhibitor. Acute an angiotensin converting enzyic effects in heart failure. Chest 1983;84:539-45.

21 Pfeffer JM, Pfeffer MA, Braunwald E. Influence of chronic captopril therapy on the infarcted left ventricle of the rat. Cir Res 1985;57:84-95.

22 Raya TE, Gay RG, Aguirre M, Goldman S. Importance of venodilation in prevention of left ventricular dilatation after chronic large myocardial infarction in rats: a compar-
ison of captopril and hydralazine. Circ Res 1989;64:330-7.

23 Brilla CG, Jalil J, Pick R, Janicki JS, Weber KT. Remodelling of the rat right and left ventricle in experimenta [Abstract]. Circulation 1989;80(suppl II):595.

24 Mukkerjee D, Sen S. Collagen phenotypes during development and regression of myocardial hypertrophy in spontaneously hypertensive rats [Abstract]. Circulation 1989, taneously hyperte

25 Jalil JE, Doering CW, Janicki JS, Pick R, Shroff SG, Weber KT. Fibrillar collagen and myocardial stiffness in the intact hypertrop

26 Weber KT, Janicki JS. Angiotensin and the remodelling of the myocardium. Br J Clin Pharmacol 1989;28:141 S-50S

27 Van der Velde ET. Non-linearity and afterload sensitivity of the end-systolic pressure-volume relation of the canine left ventricle in vivo. In: Ventricular pressure-volume relation and loading conditions in vivo. Ledien, 1989 Thesis.

28 McKay RG, Miller MJ, Ferguson JJ, et al. Assessment of left ventricular endsystolic pressure-volume relations with an impedance catheter and transient inferior ven cava occlusion: use of this system in the evaluation of the cardiotonic effects of dobutamine, milrinone, pericardia epinephrine. J Am Coll Cardiol 1986;8:1152-60.

29 Xiang J, Linz W, Becker H, et al. Effects of converting enzyme inhibitors: ramipril and enalapril on peptide action and sympathetic neurotransmission in the isolated heart. Eur J Pharmacol 1984;113:215-23. 